Research Article

\title{
Mercury, Lead, and Cadmium in the Muscles of Five Fish Species from the Mechraâ-Hammadi Dam in Morocco and Health Risks for Their Consumers
}

\author{
Mohammed Mahjoub $\mathbb{D}^{1},{ }^{1}$ Soufiane Fadlaoui, ${ }^{1}$ Mohammed El Maadoudi, ${ }^{2}$ \\ and Youssef Smiri ${ }^{1}$ \\ ${ }^{1}$ Mohamed First University, Faculty of Sciences, Department of Biology, \\ Laboratory of the Agricultural Production Improvement, Biotechnology, and Environment, P.B. 717, Oujda, Morocco \\ ${ }^{2}$ National Office of Food Safety (ONSSA), Regional Laboratory of Analysis and Research, P.B. 3, Tangier, Morocco \\ Correspondence should be addressed to Mohammed Mahjoub; mahjoub.med90@gmail.com
}

Received 2 October 2020; Revised 25 December 2020; Accepted 31 December 2020; Published 13 January 2021

Academic Editor: Zongming Ren

Copyright ( 2021 Mohammed Mahjoub et al. This is an open access article distributed under the Creative Commons Attribution License, which permits unrestricted use, distribution, and reproduction in any medium, provided the original work is properly cited.

\begin{abstract}
This study aims to assess the degree of metal contamination (mercury $(\mathrm{Hg})$, cadmium $(\mathrm{Cd})$, and lead $(\mathrm{Pb})$ ) in the muscles of five species of fish Esox lucius, Sander lucioperca, Micropterus salmoides, Lepomis macrochirus, and Scardinius erythrophthalmus, from the Mechraâ-Hammadi Dam between July 2017 and May 2018, and to conduct a risk assessment for human consumers. Trace metals were determined by Graphite Furnace Atomic Absorption Spectrometry for the $\mathrm{Pb}$ and the Cd and by Cold Vapor Atomic Absorption Spectrometry for the Hg. The results gotten from the study of the muscles of the different fish species show that the higher mean amounts of $\mathrm{Cd}$ and $\mathrm{Hg}$ were determined in E. lucius, and the maximum mean levels of $\mathrm{Pb}$ were detected in S. erythrophthalmus. Results suggested that demersal fishes inhabiting near the sediments and piscivorous fishes with higher trophic level were likely to accumulate higher trace metal concentrations. The general order of bioaccumulation of the trace metals measured in the muscles of the fish species is as follows: $\mathrm{Hg}>\mathrm{Pb}>\mathrm{Cd}$. Therefore, the bioaccumulation of $\mathrm{Hg}$ in fish studied is more important than that of $\mathrm{Cd}$ and $\mathrm{Pb}$. Furthermore, these concentrations are higher in summer than in winter for all trace metals. All the values of the trace metals in the muscle tissues are below the maximum limits recommended by the European Community (EC) $\mathrm{N}^{\circ} 1881 / 2006$. However, estimation of noncarcinogenic health risks by the target hazard quotient indicated no obvious noncarcinogenic risks to humans that consume those fishes (THQ $<1$ ). Results of THQ and maximum safe consumption indicated that $\mathrm{Hg}$ may cause more harm to human by fish consumption especially for E. lucius and S. lucioperca. Therefore, reduced intake of carnivorous fishes should be promoted as part of a healthier diet.
\end{abstract}

\section{Introduction}

The aquatic ecosystems are continuously exposed to certain pollutants that are accompanied by increasing degradation of their quality [1]; this has a negative impact on the water quality and aquatic life of our ecosystems. The pollutants that could pose a threat to our aquatic ecosystems in general and fish fauna in particular are trace metals [2]. These elements are very dangerous because of their very high toxicity even at low concentrations, their prolonged persistence in the environment, and their tendencies to bioaccumulation in aquatic organisms because they are not biodegradable, and as a result, they concentrate large quantities in their tissues [3-5]. Trace metals reach aquatic environments, through the natural pollution due to soil erosion by rain, and by anthropogenic pollution due to liquid discharges results from different urban, industrial, and agriculture activities [6,7]. In addition, revolving the bottom of the dam during the work of sludge removal may have made the metals available for the aquatic environment.

Located in Eastern Morocco, the Moulouya River is considered as the largest Moroccan river crossing several 
provinces from Midelt and leading to the Mediterranean. Three large dams are built on this river, including the Mechraâ-Hammadi Dam, which was commissioned in 1956 with a maximum storage capacity of around 6.6 million cubic meters [8]. It is a water reserve for irrigation and the production of drinking water; it also provides a fish-friendly habitat and an attractive tourist environment for sport and commercial fishing practitioners from the rural commune of Mechrâ-Hammadi and surrounding communities [9]. This dam is mainly powered by two rivers, the Moulouya River and the $\mathrm{Za}$ River which receive throughout their upstream courses, domestic and industrial liquid discharges loaded with trace metals are generated mainly by the cities of Taourirt and Guercif, and pollutants from agriculture in these areas $[10,11]$. Therefore, the fish of Mechraâ-Hammadi Dam may find themselves exposed to high concentrations of trace metals that could have adverse effects on this fauna, from a quantitative and qualitative point of view, and become toxic for human consumption. Hence, knowing the values of trace metals in these fish is of great importance for the assessment of the potential health risks associated with the consumption of fish from the Mechraâ-Hammadi Dam.

There are no studies on the contamination of fish from the Mechraâ-Hammadi Dam, and it is in this context that we undertook this study, as part of assessing metal contamination, the most concern and most dangerous trace metals, $\mathrm{Hg}, \mathrm{Cd}$, and $\mathrm{Pb}$, in the muscles of five species of fish Mechraâ-Hammadi Dam, in order to estimate the health risk they represent for their consumers by calculating the noncarcinogenic target hazard quotient (THQ) and maximum safe consumption (MSC) and to know the species most contaminated with trace metals. This study also introduces a spatiotemporal evaluation of the metallic pollution of the fish fauna of Mechraâ-Hammadi Dam.

\section{Materials and Methods}

2.1. Study Area. The Mechraâ-Hammadi Dam ( $34^{\circ} 44^{\prime} 05.0^{\prime \prime}$ $\mathrm{N} 2^{\circ} 48^{\prime} 11.0^{\prime \prime} \mathrm{W}$ ) is built on the Moulouya River, located $40 \mathrm{~km}$ far from the Mediterranean and $56 \mathrm{~m}$ above sea level in the province of Taourirt in the Eastern region of Morocco (Figure 1).

2.2. Sampling. Seasonal sampling missions were spread over the four seasons from summer of 2017 until the spring of 2018. The fish samples were captured with gill nets of various mesh sizes, after which they were euthanized by severing the spinal cord. We identified the species to which every fish belonged to using keys by Azeroual [12], and we put them in polyethylene bags, each bag of which contains individuals belong to the same species. The standard length $(\mathrm{cm})$ and weight $(\mathrm{g})$ were measured for every sample, using a vernier caliper and an analytical pocket balance, respectively, and they are transported in a cool box about $4^{\circ} \mathrm{C}$ to the laboratory, where they are stored in $-25^{\circ} \mathrm{C}$ until the instant of the analysis.
2.3. Metal Analysis. In the Regional Laboratory of Analysis and Research of National Office of Food Safety (RLAR, ONSSA) in Tangier, the fish samples are thawed, headed, and eviscerated using stainless steel scalpels, and then we take the fish flesh (edible part), grounded, then homogenized in a domestic food blender. Subsequently, we pass on to the mineralization stage of the samples carried out according to the technique described by the AOAC Official Method [13]. Of which a quantity varying between $0.5 \mathrm{~g}$ and $0.6 \mathrm{~g}$ of wet weight sample is put in Teflon vessel in the presence of $5 \mathrm{ml}$ of suprapur $(69 \%)$ nitric acid $\left(\mathrm{HNO}_{3}\right)$, for the samples that we evaluate the $\mathrm{Hg}$ content, and $5 \mathrm{ml}$ of suprapur $(69 \%) \mathrm{HNO}_{3}$ and $2 \mathrm{ml}$ of suprapur $(30 \%)$ hydrogen peroxide $\left(\mathrm{H}_{2} \mathrm{O}_{2}\right)$ for samples we assess $\mathrm{Pb}$ and $\mathrm{Cd}$ content. The Teflon vessels are hermetically closed and introduced into the microwave oven (Berghof speedway MWS-2) and gradually heated (for $45 \mathrm{~min}$ up to $185 \mathrm{C}^{\circ}$ ) until all the materials were dissolved. After digestion and cooling to room temperature, the samples are diluted by $50 \mathrm{ml}$ with ultrapure water in polyethylene tubes. $\mathrm{Pb}$ and $\mathrm{Cd}$ are determined by Graphite Furnace Atomic Absorption Spectrometry (GF-AAS) (VARIAN PERKIN ELMER ACE 800), equipped with a fully automated autosampler system. $2.5 \% \mathrm{NH}_{4} \mathrm{H}_{2} \mathrm{PO}_{4}$, and $1 \% \mathrm{Mg}\left(\mathrm{NO}_{3}\right)_{2}$ are the applied matrix modifiers. Hg is quantified by Cold Vapor Atomic Absorption Spectrometry (CV-AAS) (VARIAN FIMS 100), in the presence of a reducing solution of stannous chloride $\left(\mathrm{SnCl}_{2}\right)$ at $2.5 \%$, and the carrier solution of hydrochloric acid $(\mathrm{HCl})$ at $3 \%$. For the two spectrometry, using high purity argon as the carrier gas, their flow rate is $50 \mathrm{ml} / \mathrm{min}$.

All the tools used have been cleaned by soaking overnight in $\mathrm{HNO}_{3}(10 \%)$, rinsed with ultrapure water and dried, before each use. In addition to $\mathrm{HNO}_{3}$, the Teflon vessels have been cleaned with acetone. All of the reagents employed in this study are of analytical grade.

2.4. Quality Assurance and Quality Control. The calibration curve demonstrates a good linearity for the three trace metals, with correlation coefficients $(r)$ greater than 0.999 (Table 1). On the other hand, the limit of detection (LD), the limit of quantification (LQ), the wavelength, and the standard calibration concentration of the present study are presented in Table 1.

According to ISO 17025 [14], the accreditation laboratories that perform analytical service must have quality control procedure for monitoring the validity of tests undertaken. The methods of GF-AAS and CV-AAS were accredited in the laboratory (RLAR, ONSSA), and the accuracy of the analytical methods was evaluated by participation to proficiency test schemes. The test materials distributed were canned fish at different concentrations of $\mathrm{Cd}, \mathrm{Pb}$, and $\mathrm{Hg}$, obtained from the Food Analysis Performance Assessment Scheme (FAPAS). Replicate analysis of these proficiency tests showed good accuracy, with recovery rates for trace metals between $97.67 \%$ and $100.46 \%$ (Table 2).

2.5. Target Hazard Quotient (THQ). The concentrations of trace metals in the muscle of the five fish species studied were used to assess the noncarcinogenic health risk from the 


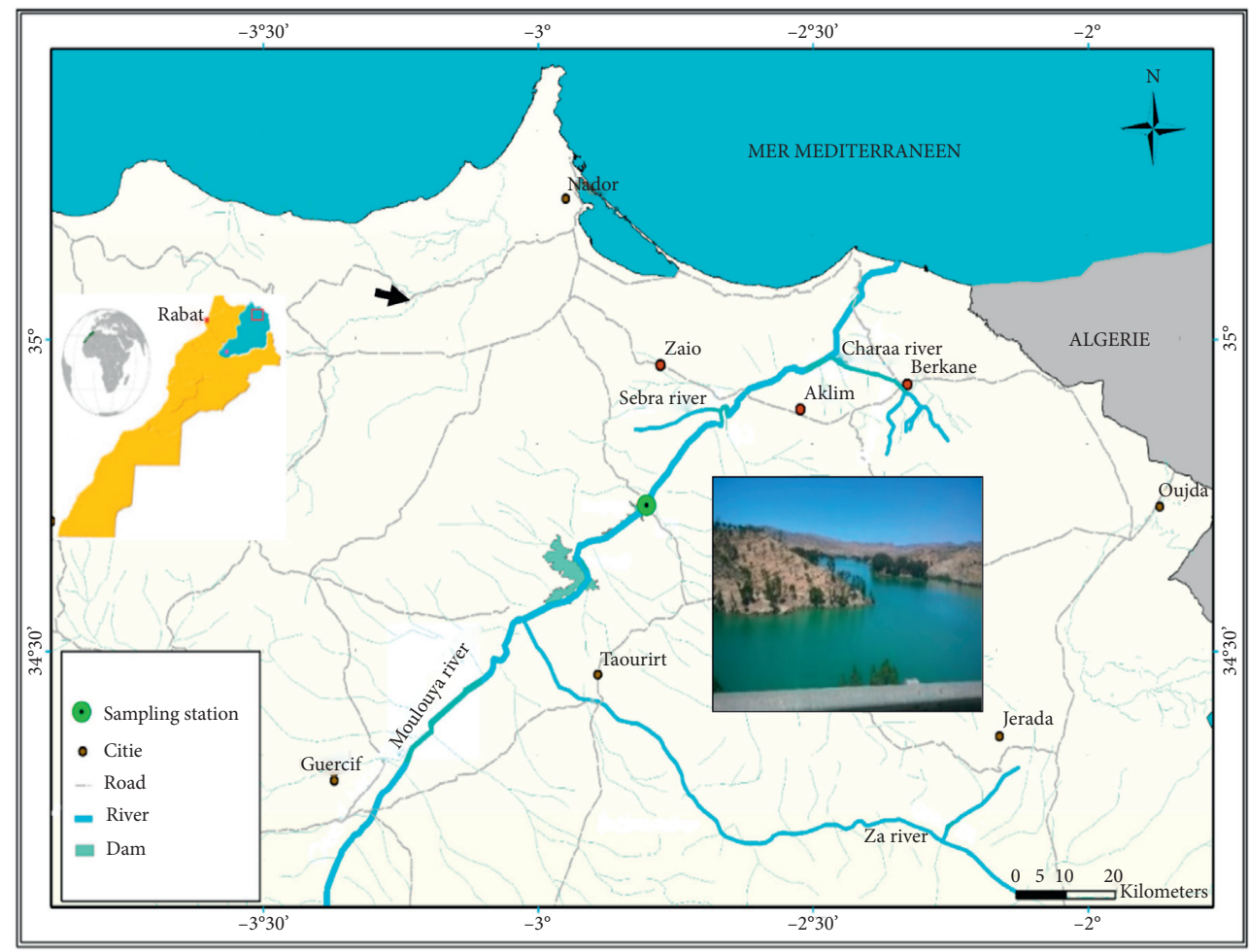

FIgURE 1: Localization map of the study area and location of sampling station area.

TABLE 1: The wavelength, limit of detection (LD), limit of quantification (LQ), standard calibration concentration, and correlation coefficient $(r)$ for trace metal determination.

\begin{tabular}{lccccc}
\hline Trace metals & Wavelength $(\mathrm{nm})$ & $\mathrm{LD}(\mu \mathrm{g} / \mathrm{kg})$ & $\mathrm{LQ}(\mu \mathrm{g} / \mathrm{kg})$ & Standard calibration concentration $(\mu \mathrm{g} / \mathrm{l})$ & Correlation coefficient $(r)$ \\
\hline $\mathrm{Cd}$ & 228.8 & 0.0027 & 0.01 & $0,0.1,0.2,0.4,0.8,1.6,3.2$ & 0.999830 \\
$\mathrm{~Pb}$ & 283.3 & 0.76 & 2.5 & $0,1,2,4,8,16,32$ & 0.999791 \\
$\mathrm{Hg}$ & 253.7 & 0.2 & 0.4 & $0,1,2.5,5,10,20$ & 0.999902 \\
\hline
\end{tabular}

consumption of this fish, using the formulas defined by the USEPA [15], and it has been reused by many authors [16-18] as follows:

$$
\begin{aligned}
\mathrm{EDI}_{i} & =\frac{C_{i} \times \mathrm{DC}}{\mathrm{BW} \times 1000}, \\
\mathrm{THQ}_{i} & =\frac{\mathrm{EDI}_{i}}{\mathrm{RfD}_{i}} \\
\mathrm{TTHQ} & =\sum_{i}^{n} \mathrm{THQ},
\end{aligned}
$$

where $\mathrm{EDI}_{i}$ is the estimated daily intake of trace metal $i$ in $\mathrm{mg} / \mathrm{kg} /$ day. $C_{i}$ is the mean concentration of trace metals $i$ in the fish muscle in $\mathrm{mg} / \mathrm{kg}$. DC is the daily consumption rate of fish per person in $\mathrm{g} /$ day/person, estimated at $13.6 \mathrm{~kg} /$ year/ person $=37.3 \mathrm{~g} /$ day/person for Morocco [19]. BW is the mean adult body weight of Moroccan adults and is estimated at $70.7 \mathrm{~kg}$ (72.1 kg for men and $69.3 \mathrm{~kg}$ for women) [20]. $\mathrm{THQ}_{i}$ is the target hazard quotient for trace metals $i . \mathrm{RfD}_{i}$ is the oral reference dose for trace metals $i$ in $\mathrm{mg} / \mathrm{kg} /$ day, and the $\mathrm{RfD}_{i}$ values of the trace metals studied are
$\mathrm{RfD}_{\mathrm{Hg}}=3 \times 10^{-4}, \quad \mathrm{RfD}_{\mathrm{Pb}}=4 \times 10^{-3}$, and $\mathrm{RfD}_{\mathrm{Cd}}=1 \times 10^{-3}$ $[16,21]$. TTHQ is the total target hazard quotient.

When THQ and TTHQ are $<1$, noncarcinogenic health risk is negligible, otherwise, it indicates greater risk and it is necessary to intervene and take protective action.

2.6. Maximum Safe Consumption (MSC). To assess the maximum safe consumption (MSC) of the five fish species studied, using the provisional tolerable weekly intake (PTWI), the MSC was calculated according to the equation described by Metian et al. [22] as follows:

$$
\mathrm{MSC}_{i}=\frac{\mathrm{BW} \times \mathrm{JL}_{i}}{C_{i}}
$$

where $\mathrm{MSC}_{i}$ is the maximum safe consumption of fooding/ week items in relation with a contaminant $i$. BW is the body weight $(\mathrm{kg})$ of the human for whom the assessment of the $\mathrm{MSC}_{i}$ is carried out. $\mathrm{JL}_{i}$ represents the PTWI of a trace metal $i$; according to the FAO/WHO [23], the PTWI for $\mathrm{Cd}, \mathrm{Pb}$, and $\mathrm{Hg}$ are 7,25 , and $4 \mu \mathrm{g} / \mathrm{kg} /$ week, respectively. $C_{i}$ is the mean concentration of a trace metal $i$ in fish muscle in $\mu \mathrm{g} / \mathrm{kg}$. 
2.7. Statistical Analyses. Statistical analyses of the data were performed using the IBM SPSS Statistics 21 program. The level of statistical significance was defined at 95\% $(p<0.05)$. A Pearson correlation test was used to examine the relationships between trace metals in the muscle tissue of different fish species.

\section{Results}

3.1. Trace Metals in Muscles of Fish Species. The number of fish and the biometric parameters (weight and length) of the fish species are summarized in Table 3. Also, the results of the evaluation of the mean concentrations of $\mathrm{Hg}, \mathrm{Pb}$, and $\mathrm{Cd}$ in the muscles of the different fish species collected from the Mechraâ-Hammadi Dam are shown in Table 4.

The results of $\mathrm{Cd}$ concentration in the analyzed fish species are low. They vary from $0.001 \mathrm{mg} / \mathrm{kg}$ of wet weight obtained in L. macrochirus to $0.005 \mathrm{mg} / \mathrm{kg}$ of wet weight in E. lucius (Table 4). An order of accumulation of Cd can be established in the muscles of the fish species studied. The result is obtained in Table 5, through which this order of bioaccumulation is slightly elevated in E. lucius.

The concentration of $\mathrm{Pb}$ revealed in the muscles of the fish studied shows that the lowest content is in the order of $0.017 \mathrm{mg} / \mathrm{kg}$ of wet weight in M. salmoides, while the highest value is in the order of $0.115 \mathrm{mg} / \mathrm{kg}$ of the wet weight obtained in L. macrochirus (Table 4 ). $\mathrm{Pb}$ accumulation order can be established, and the result is obtained in Table 5, of which this order of bioaccumulation is slightly elevated in S. erythrophthalmus.

For $\mathrm{Hg}$ concentrations measured in the muscles of fish, we have obtained results that vary from $0.056 \mathrm{mg} / \mathrm{kg}$ of wet weight in $M$. salmoides to $0.287 \mathrm{mg} / \mathrm{kg}$ of wet weight in E. lucius (Table 4). An order of accumulation of $\mathrm{Hg}$ can be established in the muscles of the fish species studied, and the result is obtained in Table 5. Of which this order of bioaccumulation is high in E. lucius.

Interelemental relationships in fish muscles (intermetal correlation) were assessed by the mean of Person's correlation coefficient, and this is presented in Table 6 . No significant correlation was obtained at a level of significance $(p<0.05)$ which has been found between trace metals in different fish species of the Mechraâ-Hammadi Dam (Table 6).

Comparison of the mean trace metal concentrations detected in the muscles of the fish species studied shows that the $\mathrm{Hg}$ content are the highest compared to those of $\mathrm{Pb}$ and $\mathrm{Cd}$, and the only variation is related to the high $\mathrm{Pb}$ content in S. erythrophthalmus (Table 7 ). From these results, we can establish the general order of bioaccumulation of the trace metals measured in the muscles of the different fish species which is as follows: $\mathrm{Hg}>\mathrm{Pb}>\mathrm{Cd}$.

Finally, for the seasonal variation in trace metals in the muscles of the fish species studied, important values are shown in summer, while winter records the lowest values in trace metals (Figure 2).

3.2. Estimation of Potential Public Health Risks. The estimation of the noncarcinogenic health risks to Moroccan people through the consumption of fish from the Mechraâ-
Hammadi Dam was assessed by calculating the target hazard quotients $\left(\mathrm{THQ}_{i}\right)$ and the total target hazard quotient (TTHQ). Results indicated that THQ values for individual trace metals varied among fishes, where the THQ results revealed that $\mathrm{Hg}$ had the highest values (0.1236 to 0.3069$)$, followed by $\mathrm{Pb}(0.0041$ to 0.0114$)$, and then $\mathrm{Cd}(0.0012$ to 0.0021 ) in this descending order $\mathrm{Hg}>\mathrm{Pb}>\mathrm{Cd}$ (Table 8). Whose THQ and TTHQ are $<1$ for all trace metals.

The maximum safe weekly consumption of fish species from the Mechraâ-Hammadi Dam has been calculated for adults who have the same average body weight of Moroccan adults $(70.7 \mathrm{~kg})$. The MSC for adult consumers was above $123,725 \mathrm{~g} /$ week for $\mathrm{Cd}$, above 20,505 g/week for $\mathrm{Pb}$, and above $1621 \mathrm{~g} /$ week for $\mathrm{Hg}$ (Table 9).

\section{Discussion}

$\mathrm{Cd}$ is a nonessential element and is considered one of the most toxic elements to humans, fishes, and environment, due to its capability of producing a chronic toxic effect even at a low concentration level [24]. These levels are all lower the European Community (regulation (EC) $\mathrm{N}^{\circ} 1881 / 2006$ ) for Cd in fish flesh, which is in the order of $0.05 \mathrm{mg} / \mathrm{kg}$ of wet weight for muscle meat of fish [25]. The lower concentration of Cd in muscle observed in this study suggests that muscle tissue is not an active site for the $\mathrm{Cd}$ accumulation process. In the scientific literature, similar values were recorded in the muscles of L. macrochirus, B. callensis, and B. nasus from the Moulouya River to Morocco [26], in the muscles of L. graellsii, R. rutilus, and L. gibbosus in the station 1 from the Llobergat River to Spain [27], and in C. carpio of Kasumigaura Lake in Japan [6]. While, low concentrations of Cd were found in the muscles of B. barbus, and L. cephalus from the Shahid Rajaei Dam in northern Iran [28], in the muscles of ten species caught at Šalek Lake in Slovenia [29], in fish B. barbatula, S. cephalus, and B. barbus from the Sûre River in Luxembourg [30], in three species from the Vaal Dam in South Africa [31], and in the muscles of T. nilotica from the High Dam Lake in Egypt [32]. On the other hand, some studies have shown high concentrations of $\mathrm{Cd}$ in the muscles of fish species, such as the study of Özparlak et al. [33] on nine fish species from Beyşehir Lake in Turkey, the work of Bahnasawy et al. [34] in the muscle of $M$. cephalus and L. ramada, and the study of Rajotte et al. [35] of the species $P$. flavescens in, namely, Ramsey, Nelson, Vermilion, and Whitson lakes in Canada (Table 10).

Similar to $\mathrm{Cd}, \mathrm{Pb}$ is a serious environmental contaminant and is toxic to fish and human even in small quantities [24]. These levels detected in this study are all lower the European Community (regulation (EC) $\mathrm{N}^{\circ} 1881 / 2006$ ) for the $\mathrm{Pb}$ in fish flesh, which is in the order of $0.3 \mathrm{mg} / \mathrm{kg}$ of wet weight for muscle meat of fish [25]. The comparison with the data available in the literature indicated that similar concentrations of $\mathrm{Pb}$ were detected in the muscles of L. kimberleyensis from Vaal Dam to South Africa [36], in L. macrochirus, B. callensis, and B. nasus captured at the Moulouya River to Morocco [26], in the muscles of L. graellsii, R. rutilus, and L. gibbosus in the station 1 from the Llobergat River to Spain [27], and in G. holbrooki from Fouarat Lake and Sebou Estuary in Morocco 
TABLE 2: Trace metal determination in proficiency tests (FAPAS canned fish samples).

\begin{tabular}{lccc}
\hline Trace metals & Reference value $(\mathrm{mg} / \mathrm{kg}) \pm \mathrm{SD}$ & Observed value $(\mathrm{mg} / \mathrm{kg}) \pm \mathrm{SD}$ & Recovery $(\%)$ \\
\hline $\mathrm{Cd}$ & $6.2100 \pm 1.5100$ & $6.0655 \pm 0.2636$ & 97.67 \\
$\mathrm{~Pb}$ & $0.0526 \pm 0.0232$ & $0.0515 \pm 0.0083$ & 97.91 \\
$\mathrm{Hg}$ & $0.1080 \pm 0.0455$ & $0.1085 \pm 0.0129$ & 100.46 \\
\hline
\end{tabular}

SD: standard deviation.

TABLE 3: Number of fish species and weight and length of the studied fish species.

\begin{tabular}{|c|c|c|c|c|c|}
\hline \multirow{2}{*}{ Species } & \multirow{2}{*}{$n$} & \multicolumn{2}{|c|}{ Weight (g) } & \multicolumn{2}{|c|}{ Length $(\mathrm{cm})$} \\
\hline & & $\bar{X} \pm \mathrm{SD}$ & $m-M$ & $\bar{X} \pm \mathrm{SD}$ & $m-M$ \\
\hline E. lucius & 10 & $451.7 \pm 231.98$ & $303-1095$ & $40.75 \pm 6.86$ & $35.1-58.6$ \\
\hline S. lucioperca & 9 & $427.89 \pm 94.98$ & $283-610$ & $37.49 \pm 2.99$ & $33.1-42.6$ \\
\hline M. salmoides & 23 & $148.13 \pm 48.52$ & $51-215$ & $21.7 \pm 2.57$ & $15.5-25.2$ \\
\hline L. macrochirus & 35 & $75.83 \pm 23.16$ & $35-130$ & $14.5 \pm 2.78$ & $9.3-20.1$ \\
\hline S. erythrophthalmus & 22 & $372.24 \pm 91.35$ & $210-580$ & $25.93 \pm 4.96$ & $17-36$ \\
\hline
\end{tabular}

$n$ : number of fish; $\bar{X}$ : mean; SD: standard deviation; $m$ : minimum; $M$ : maximum.

TABle 4: Contents of trace metals dosed in the muscles of fish species collected from the Mechraâ-Hammadi Dam (mg/kg of wet weight).

\begin{tabular}{lcccccc}
\hline Species & \multicolumn{2}{c}{$\mathrm{Cd}$} & \multicolumn{2}{c}{$\mathrm{Pb}$} & $\mathrm{Hg}$ & \\
& $\bar{X} \pm \mathrm{SD}$ & $m-M$ & $\bar{X} \pm \mathrm{SD}$ & $m-M$ & $\bar{X} \pm \mathrm{SD}$ & $m-M$ \\
\hline E. lucius & $0.004 \pm 0.0008$ & $0.003-0.005$ & $0.0518 \pm 0.019$ & $0.034-0.074$ & $0.1745 \pm 0.1149$ \\
S. lucioperca & $0.0033 \pm 0.0005$ & $0.003-0.004$ & $0.0675 \pm 0.0187$ & $0.045-0.087$ & $0.1578 \pm 0.0973$ & $0.071-0.287$ \\
M. salmoides & $0.0028 \pm 0.0009$ & $0.002-0.004$ & $0.0313 \pm 0.0116$ & $0.017-0.043$ & $0.108 \pm 0.0557$ & $0.056-0.161$ \\
L. macrochirus & $0.0023 \pm 0.0009$ & $0.001-0.003$ & $0.0810 \pm 0.0327$ & $0.051-0.115$ & $0.1028 \pm 0.0296$ & $0.078-0.140$ \\
S. erythrophthalmus & $0.0038 \pm 0.0005$ & $0.003-0.004$ & $0.0862 \pm 0.0254$ & $0.049-0.106$ & $0.0703 \pm 0.0182$ & $0.043-0.081$ \\
\hline
\end{tabular}

$\overline{\mathrm{X}}$ : mean; SD: standard deviance; $m$ : minimum, $M$ : maximum.

TABLE 5: The order of the bioaccumulation of trace metals in the muscles of the studied fish species.

\begin{tabular}{ll}
\hline Trace metals & \multicolumn{1}{c}{ Order of metal bioaccumulation } \\
\hline $\mathrm{Cd}$ & E. lucius $>$ S. erythrophthalmus $>$ S. lucioperca $>$ M. salmoides $>$ L. macrochirus \\
$\mathrm{Pb}$ & S. erythrophthalmus $>$ L. macrochirus $>$ S. lucioperca $>$ E. lucius $>M$. salmoides \\
$\mathrm{Hg}$ & E. lucius $>$ S. lucioperca $>$ M. salmoides $>$ L. macrochirus $>$ S. erythrophthalmus \\
\hline
\end{tabular}

TABLE 6: Matrix of correlation between the different trace metals in different fish species.

\begin{tabular}{lccc}
\hline & $\mathrm{Cd}$ & $\mathrm{Pb}$ & $\mathrm{Hg}$ \\
\hline $\mathrm{Cd}$ & 1 & & \\
$\mathrm{~Pb}$ & 0.16742944 & 1 & \\
$\mathrm{Hg}$ & 0.26232459 & -0.4331575 & 1 \\
\hline
\end{tabular}

TABle 7: Order of trace metals accumulated in the fish muscles from the Mechraâ-Hammadi Dam.

\begin{tabular}{lc}
\hline Species & Order \\
\hline E. lucius & $\mathrm{Hg}>\mathrm{Pb}>\mathrm{Cd}$ \\
S. lucioperca & $\mathrm{Hg}>\mathrm{Pb}>\mathrm{Cd}$ \\
M. salmoides & $\mathrm{Hg}>\mathrm{Pb}>\mathrm{Cd}$ \\
L. macrochirus & $\mathrm{Hg}>\mathrm{Pb}>\mathrm{Cd}$ \\
S. erythrophthalmus & $\mathrm{Pb}>\mathrm{Hg}>\mathrm{Cd}$ \\
\hline
\end{tabular}

[37]. However, low concentrations of $\mathrm{Pb}$ were found by Rashed et al. [32], Wariaghli et al. [38], Alam et al. [6], Boscher et al. [30], Plessl et al. [31], and Petkovšek et al. [29]. On the other hand, several studies have shown high concentrations of $\mathrm{Pb}$, such as the study of Bahnasawy et al. [34] in the muscle of M. cephalus and L. ramada, the work of Özparlak et al. [33] on nine fish species, and the study of Alhas et al. [39] on B. xanthopterus and B. rajanorum mystaceus (Table 10). The order of bioaccumulation of $\mathrm{Pb}$ indicates that omnivorous fish living near sediments such as S. erythrophthalmus and L. macrochirus accumulated the largest quantities of this metal. This can be explained by the fact that these fish species are likely to have more contact with contaminated sediments, and as a result, metals contained in sediments are absorbed and stored in the fish tissues $[27,40]$. This supported the hypothesis that the sediment was the major pathway for trace metal uptake for fish [41]. The high levels of $\mathrm{Pb}$ in S. erythrophthalmus and L. macrochirus compared to other species can also be attributed to the consumption of zoobentics, which have high concentrations of trace metals [42]. Our result agrees well with the conclusion of Yi et al. [42] on the order of accumulation of trace metals in different fish species, which is as follows: benthic invertivores $>$ piscivores $>$ zooplanktivores $>$ phytophagic fishes $>$ phytoplanktivores. Indeed, the origin of difference in 


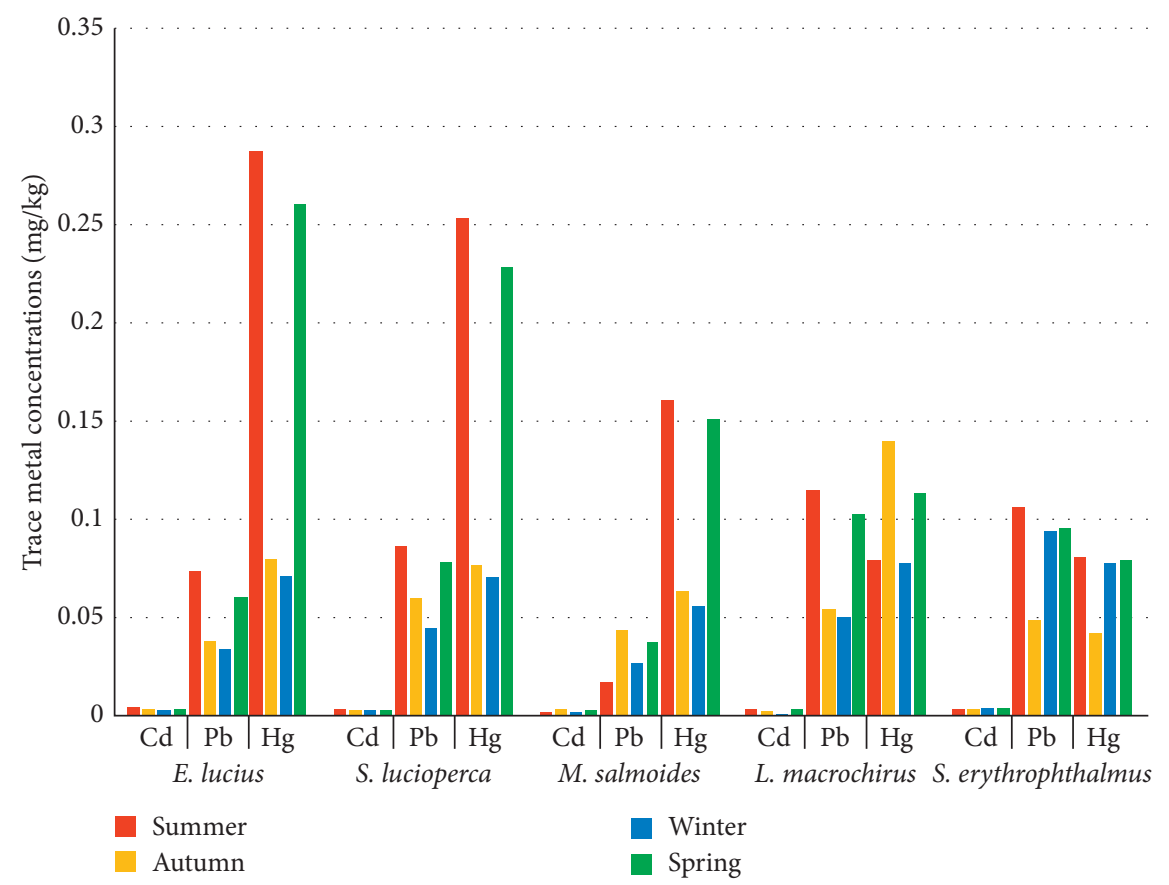

FIGURE 2: Seasonal variation in mean trace metal concentrations in muscles of the five fish species from the Mechraâ-Hammadi Dam in Morocco ( $\mathrm{mg} / \mathrm{kg}$ of wet weight).

TABLE 8: Target hazard quotient (THQ) and total THQ (TTQH) calculated for each species.

\begin{tabular}{lcccc}
\hline Species & \multicolumn{3}{c}{ THQ } \\
& $\mathrm{Cd}$ & $\mathrm{Pb}$ & $\mathrm{Hg}$ & TTHQ \\
\hline E. lucius & 0.0021 & 0.0068 & 0.3069 & 0.3158 \\
S. lucioperca & 0.0017 & 0.0089 & 0.2775 & 0.2882 \\
M. salmoides & 0.0015 & 0.0041 & 0.1899 & 0.1955 \\
L. macrochirus & 0.0012 & 0.0107 & 0.1808 & 0.1927 \\
S. erythrophthalmus & 0.0020 & 0.0114 & 0.1236 & 0.1370 \\
\hline
\end{tabular}

TABle 9: Maximum safe consumption for $\mathrm{Cd}, \mathrm{Pb}$, and $\mathrm{Hg}$ in fish from the Mechraâ-Hammadi Dam (g fish/week).

\begin{tabular}{lccc}
\hline Species & $\mathrm{Cd}$ & $\mathrm{Pb}$ & $\mathrm{Hg}$ \\
\hline E. lucius & 123725 & 34122 & 1621 \\
S. lucioperca & 149970 & 26185 & 1792 \\
M. salmoides & 176750 & 56470 & 2619 \\
L. macrochirus & 215174 & 21821 & 2751 \\
S. erythrophthalmus & 130237 & 20505 & 4023 \\
\hline
\end{tabular}

bioaccumulation could be related to differences in diet, trophic level, metabolism, type of trace metal, preferred habitat, and lifestyle of these fish species [27, 43, 44].

$\mathrm{Hg}$ is a serious environmental pollutant and toxic to aquatic biota and humans even in low contents [5]. $\mathrm{Hg}$ amounts detected in this study are all below the European Community (regulation (EC) $\mathrm{N}^{\circ} 1881 / 2006$ ) for $\mathrm{Hg}$ in fish flesh, which is in the order of $0.5 \mathrm{mg} / \mathrm{kg}$ of wet weight in fish at the bottom of the food chain, and $1 \mathrm{mg} / \mathrm{kg}$ of wet weight in fish at higher in the food chain [25]. Comparing the results of our study with previous studies, we found that the study of
Boscher et al. [30] presented similar results in fish B. barbatula, S. cephalus, and B. barbus captured at the Sûre River in Luxembourg, while this metal is not detected in the muscles of six species belong to the Atatürk Dam studied by Karadede et al. [45]. Other studies show low levels of $\mathrm{Hg}$ in fish muscles, such as the study of Petkovšek et al. [29] on ten species caught at Šalek Lake in Slovenia, the study of Mahjoub et al. [26] on L. macrochirus, B. callensis, and B. nasus captured at the Moulouya River in Morocco, the work of Mol et al. [46] on eight species of the Atatürk Dam in Turkey, and the study of Plessl et al. [31] on three species from the Vaal Dam in South Africa. On the contrary, some studies have shown high levels of $\mathrm{Hg}$ exceeding the recommended regulatory limits, such as the study of Dharampal et al. [47] on $M$. salmoides from the Sipsey River in the USA, the study of Scerbo et al. [48] on species of A. anguilla, L. cephalus cabeda, and $C$. toxostoma captured at the Cecina River in Italy, and the work of Shakeri et al. [28] on B. barbus from the Shahid Rajaei Dam in northern Iran (Table 10). We notice from the results of bioaccumulation order that the $\mathrm{Hg}$ concentrates in predatory fish are already recognized for their great power to accumulate trace metals, as seen in the species of E. lucius, S. lucioperca, and M. salmoides (mercury values up to 0.287; $0.254,0.161 \mathrm{mg} / \mathrm{kg}$ of wet weight, respectively), and this fact can be explained by the affinity of $\mathrm{Hg}$ for the sulfhydryl groups of fish flesh proteins [49] and underlines that muscle is the main target of $\mathrm{Hg}$ storage [50]. Therefore, these relatively high concentrations of $\mathrm{Hg}$ in the muscles of these fish may not be directly related to their concentrations in water but are due to the phenomena of bioaccumulation and biomagnification [51]. The lowest contents of $\mathrm{Hg}$ were found in the muscle of S. erythrophthalmus, whose diet consists mainly of water plants, insects, and crustaceans [52]. 
TABLE 10: Comparisons of recorded trace metal levels in the muscles of the fish species during the present study with the literature reported from different areas ( $\mathrm{mg} / \mathrm{kg}$ of wet weight).

\begin{tabular}{|c|c|c|c|c|c|}
\hline Fish species & Region & $\mathrm{Cd}$ & $\mathrm{Pb}$ & $\mathrm{Hg}$ & References \\
\hline C. carpio & $\begin{array}{l}\text { Kasumigaura Lake } \\
\text { (Japan) }\end{array}$ & 0.009 & 0.031 & - & {$[6]$} \\
\hline L. macrochirus, B. callensis, and B. nasus & $\begin{array}{l}\text { Moulouya River } \\
\text { (Morocco) }\end{array}$ & $0.001-0.006$ & $0.016-0.200$ & $0.009-0.187$ & {$[26]$} \\
\hline L. graellsii, R. rutilus, and L. gibbosus & $\begin{array}{l}\text { Station } 1 \text { from the } \\
\text { Llobregat River } \\
\text { (Spain) }\end{array}$ & $\begin{array}{l}0.007,0.004,0.009 \\
\text { resp. }\end{array}$ & $\begin{array}{c}0.095,0.107,0.078 \\
\text { resp. }\end{array}$ & - & {$[27]$} \\
\hline B. barbus and L. cephalus & $\begin{array}{l}\text { Shahid Rajaei Dam } \\
\text { (Iran) }\end{array}$ & $0.018,0.04$, resp. & - & $0.7,0.37$, resp. & {$[28]$} \\
\hline $\begin{array}{l}\text { A. brama danubii, A. alburnus, } \\
\text { B. meridionalis petenyi, C. auratus gibelio, } \\
\text { C. carpio, L. gibbosus, L. cephalus, } \\
\text { P. fluviatilis, R. rutilus, and } \\
\text { S. erythrophthalmus }\end{array}$ & $\begin{array}{l}\text { Šalek Lake } \\
\text { (Slovenia) }\end{array}$ & $\leq 0.01$ & $0.01-0.04$ & $0.03-0.16$ & {$[29]$} \\
\hline B. barbatula, S. cephalus, and B. barbus & $\begin{array}{l}\text { Sure River } \\
\text { (Luxembourg) }\end{array}$ & $\begin{array}{l}0.024,0.027,0.028 \\
\text { resp. }\end{array}$ & $\begin{array}{l}0.037,0.018,0.034 \\
\text { resp. }\end{array}$ & $\begin{array}{l}\text { 0.037, 0.298, } \\
0.096, \text { resp. }\end{array}$ & {$[30]$} \\
\hline $\begin{array}{l}\text { L. aeneus, L. kimberleyensis, and } \\
\text { L. umbratus }\end{array}$ & $\begin{array}{l}\text { Vaal Dam (South } \\
\text { Africa) }\end{array}$ & $<0.0012$ & $\begin{array}{l}\text { 0.012, } 0.007,0.008 \\
\text { resp. }\end{array}$ & $\begin{array}{c}0.096,0.133 \\
0.05, \text { resp. }\end{array}$ & {$[31]$} \\
\hline T. nilotica & $\begin{array}{l}\text { High Dam Lake } \\
\text { (Egypt) }\end{array}$ & 0.018 & 0.13 & - & {$[32]$} \\
\hline $\begin{array}{l}\text { P. anatolicus, A. akili, G. gobio } \\
\text { microlepidotus, L. lepidus, C. gibelio, } \\
\text { C. carpio, S. erythrophthalmus, } \\
\text { S. lucioperca, and T. tinca }\end{array}$ & $\begin{array}{l}\text { Beyşehir Lake } \\
\text { (Turkey) }\end{array}$ & $\begin{array}{l}0.8,0.8,0.47,0.43 \\
0.46,0.43,0.46,0.43 \\
0.55, \text { resp. }\end{array}$ & $\begin{array}{l}0.57,1.05,0.71,0.4 \\
0.5,0.57,0.39,0.32 \\
0.67, \text { resp. }\end{array}$ & - & {$[33]$} \\
\hline M. cephalus and L. ramada & $\begin{array}{c}\text { Manzala Lake } \\
\text { (Egypt) }\end{array}$ & $\begin{array}{c}0.216-0.334 \\
0.102-0.222, \text { resp. }\end{array}$ & $\begin{array}{c}0.332-0.596 \\
0.286-0.486, \text { resp. }\end{array}$ & - & {$[34]$} \\
\hline P. flavescens & $\begin{array}{l}\text { A range of Lakes } \\
(\text { Canada })\end{array}$ & $0.338-2.598$ & - & - & {$[35]$} \\
\hline L. kimberleyensis & $\begin{array}{c}\text { Vaal Dam (South } \\
\text { Africa) }\end{array}$ & - & 0.101 & - & {$[36]$} \\
\hline G. holbrooki & $\begin{array}{l}\text { Fouarat Lake and } \\
\text { Sebou } \\
\text { Estuary (Morocco) } \\
\text { Moulay }\end{array}$ & - & $0.0002-0.1967$ & - & {$[37]$} \\
\hline A. anguilla & $\begin{array}{c}\text { Bousselham } \\
\text { Lagoon (Morocco) }\end{array}$ & - & 0.002 & - & {$[38]$} \\
\hline $\begin{array}{l}\text { B. xanthopterus, and B. rajanorum } \\
\text { mystaceus }\end{array}$ & $\begin{array}{l}\text { Atatürk Dam } \\
\text { (Turkey) }\end{array}$ & Not detected & $0.68,0.66$, resp. & - & {$[39]$} \\
\hline $\begin{array}{l}\text { C. regium, A. marmid, C. trutta, } \\
\text { C. mossulensis, C. luteus, and C. carpio }\end{array}$ & $\begin{array}{l}\text { Atatürk Dam } \\
\text { (Turkey) }\end{array}$ & Not detected & Not detected & Not detected & {$[45]$} \\
\hline $\begin{array}{l}\text { S. triostegus, A. marmid, A. vorax, C. trutta, } \\
\text { C. luteus, C. mossulens, and C. carpio }\end{array}$ & $\begin{array}{l}\text { Atatürk Dam } \\
\text { (Turkey) }\end{array}$ & - & - & $0.011-0.130$ & {$[46]$} \\
\hline M. salmoides & Sipsey River (USA) & - & - & 0.87 & {$[47]$} \\
\hline $\begin{array}{l}\text { A. anguilla, L. cephalus cabeda, and } \\
\text { C. toxostoma }\end{array}$ & Cecina River (Italy) & - & - & $\begin{array}{l}0.82,0.558 \\
0.65, \text { resp. }\end{array}$ & {$[48]$} \\
\hline
\end{tabular}

Tissue concentrations found in dry weight were converted to wet weight by multiplying by a factor of 0.2 (considering an average water content in fish tissues of $80 \%)$ [54].

The general order of metal bioaccumulation measured in the muscles of the different fish species studied was $\mathrm{Hg}>\mathrm{Pb}>\mathrm{Cd}$. We have noted that $\mathrm{Cd}$ is the less accumulated metal, because he has a low tendency to accumulate in muscles $[16,53]$, where the concentrations are usually very low. Several studies have demonstrated that $\mathrm{Cd}$ preferentially accumulates in active metabolic organs, such as kidney and liver [16]. Unlike Cd, Hg preferentially accumulates in muscles due to their affinity for the sulfhydryl groups of proteins [49]. Therefore, there is an evidence for $\mathrm{Hg}$ bioaccumulation and biomagnification; however, evidence for Cd biomagnifications is inconsistent [2].
The fish of the Mechraâ-Hammadi Dam has relatively high values in trace metals, and particularly for $\mathrm{Hg}$ and $\mathrm{Pb}$, this station is permanently subject to the urban contributions of the agglomerations located upstream of the Mechraâ-Hammadi Dam like that of Taourirt and Guercif, as well as the discharges of the oil mills of Taourirt and Guercif $[8,10]$. These discharges can be considered as the most important sources of pollution of fish by trace metals studied. Additionally, the possibility of leaching of agricultural lands of the surroundings areas of this reservoir can be given in terms of sources of trace metals in this station. 
Seasonal variations were also observed in the data collected. Higher values were obtained during summer season than during winter season, and this may be due to the increase in the volume of water in the dam by the supply of storm water, induced their dilutions in winter. Moreover, the very high temperatures in the summer could also lead to higher metabolic rates, which could induce an increase in fish food activity, and this in turn increases the concentration of metals in fish $[26,55,56]$. This result agrees well with some studies $[26,56,57]$.

Concerning the estimation of the potential public health risks, noncarcinogenic health risk was assessed by the calculation of THQ and TTHQ values for $\mathrm{Cd}, \mathrm{Pb}$, and $\mathrm{Hg}$ from the consumption of fish by adults. In the present study, THQ and TTHQ results were fewer than 1 in adult consumers for all three trace metals, suggesting that people would not experience significant health risks from the intake of fish species from the Mechraâ-Hammadi Dam. However, according to the calculation formula already cited, the value of THQ depends on the trace metal concentration in fish, the age and weight of consumers, and the rate of fish ingestion. Therefore, excess fish consumption in a Mechraâ-Hammadi Dam population may easily to THQ $>1$. In this study, the major risk contributor is $\mathrm{Hg}$, with the highest THQ value of 0.3069 and 0.2775 for E. lucius and S. lucioperca, respectively, in adult consumers.

For the maximum safe weekly consumption, $\mathrm{Hg}$ appears as the only trace metal of concern regarding the consumption of Mechraâ-Hammadi Dam fish (mainly for predatory fish: E. lucius and S. lucioperca), where the maximum amount of E. lucius and S. lucioperca that should be eaten by a $70.7 \mathrm{~kg}$ adult person to reach the PTWI for $\mathrm{Hg}$ is about $1621 \mathrm{~g}$ and $1792 \mathrm{~g}$ over a week, respectively. These results indicated that $\mathrm{Hg}$ may cause more harm to human by fish consumption, and the consumption of E. lucius and S. lucioperca should be limited the most (should be below $1621 \mathrm{~g} /$ week and $1792 \mathrm{~g} /$ week, respectively) in order to avoid the negative effect of $\mathrm{Hg}$, while the concentrations of $\mathrm{Cd}$ and $\mathrm{Pb}$ in fish species were safe for consumption.

\section{Conclusions}

The results obtained after the dosage of $\mathrm{Hg}, \mathrm{Pb}$, and $\mathrm{Cd}$ in the muscles of five fish species captured from the MechraâHammadi Dam allow us to conclude as follows:

(i) $\mathrm{Hg}$ contents are the highest compared to those of $\mathrm{Pb}$ and $\mathrm{Cd}$, whose general order of metal bioaccumulation measured in the muscles of the different fish species is $\mathrm{Hg}>\mathrm{Pb}>\mathrm{Cd}$.

(ii) The accumulation of metals was more pronounced in E. lucius (carnivorous fish) for $\mathrm{Hg}$ and $\mathrm{Cd}$ and was more pronounced in $S$. erythrophthalmus (demersal fish) for $\mathrm{Pb}$. Metal levels vary between fish species due to their differences in food habits, type of trace element, and their lifestyles.

(iii) Summer is the season during which it records the highest concentrations of metals in the fish studied while winter records the lowest concentrations. (iv) The concentrations of the three metals in the muscles of the fish studied have values below the regulatory limits of the European Community (EC). According to the THQ and MSC calculations, Hg may cause nonignorable health effects in humans if these species (especially E. lucius and S. lucioperca) are consumed at a larger amount, whereas remaining elements will not pose any adverse health effects to humans.

\section{Data Availability}

The data used to support the findings of this study are available from the corresponding author upon request.

\section{Conflicts of Interest}

The authors declare that there are no conflicts of interest regarding the publication of this work.

\section{Acknowledgments}

The authors are grateful to the Regional Laboratory of Analysis and Research of National Office of Food Safety (RLAR, ONSSA) in Tangier for sample analyses. Special thanks go to Pr. Mohammed Ghziyel and Dr. Yassine Kaddouri for editing English language of the whole text.

\section{References}

[1] M. El Morhit, M. Fekhaoui, A. El Morhit et al., "Hydrochemical characteristics and metallic quality in fish in the loukkos river estuary of Morocco," Journal of Materials and Environmental Science, vol. 4, no. 6, pp. 893-904, 2013.

[2] I. Afandi, S. Talba, A. Benhra et al., "Trace metal distribution in pelagic fish species from the north-west African coast (Morocco)," International Aquatic Research, vol. 10, no. 2, pp. 191-205, 2018.

[3] A. Arulkumar, S. Paramasivam, and R. Rajaram, "Toxic heavy metals in commercially important food fishes collected from Palk Bay, Southeastern India," Marine Pollution Bulletin, vol. 119, no. 1, pp. 454-459, 2017.

[4] Z. Wu, Y. Xu, M. Cai et al., "Metals in fishes from Yongshu Island, Southern South China sea: human health risk assessment," Journal of Toxicology, vol. 2017, Article ID 2458293, 12 pages, 2017.

[5] A. Arumugam, J. Li, P. Krishnamurthy et al., "Investigation of toxic elements in Carassius gibelio and Sinanodonta woodiana and its health risk to humans," Environmental Science and Pollution Research, vol. 27, pp. 19955-19969, 2020.

[6] M. G. M. Alam, A. Tanaka, G. Allinson, L. J. B. Laurenson, F. Stagnitti, and E. T. Snow, "A comparison of trace element concentrations in cultured and wild carp (Cyprinus carpio) of lake Kasumigaura, Japan," Ecotoxicology and Environmental Safety, vol. 53, no. 3, pp. 348-354, 2002.

[7] N. Malik, A. K. Biswas, T. A. Qureshi, K. Borana, and R. Virha, "Bioaccumulation of heavy metals in fish tissues of a freshwater lake of Bhopal," Environmental Monitoring and Assessment, vol. 160, no. 1-4, pp. 267-276, 2010.

[8] A. Tovar-Sánchez, G. Basterretxea, M. Ben omar et al., "Nutrients, trace metals and B-vitamin composition of the Moulouya River: a major north African river discharging into 
the mediterranean sea," Estuarine, Coastal and Shelf Science, vol. 176, pp. 47-57, 2016.

[9] M. Melhaoui and J. P. Boudot, "Diagnostic de la biodivesité aquatique dans le bassin hydraulique de la Moulouya," Projet UICN/ABHM Moulouya-Maroc, rapport d'expertise, UICN Medicine, 2009, https://lemondedecathy.fr/image/2014/04/ diagnostic_de_la_biodiversite_aquatique_fr.pdf.

[10] A. Brahimi, A. Chafi, N. Nouayti et al., "Metal typology contamination of surface waters of Za River, lower Moulouya, eastern Morocco," Der Pharma Chemica, vol. 7, no. 9, pp. 346-353, 2015.

[11] A. Fahssi, H. S. Ali Yahya, R. Touzani et al., "Evaluation spatiotemporelle de la contamination metallique des ressources hydriques superficielles de la basse Moulouya," Journal of Materials and Environmental Science, vol. 7, no. 7, pp. 2404-2423, 2016.

[12] Azeroual, Monographie des Poissons des eaux continentales du Maroc: systématique, distribution et écologie, Faculté des Sciences, Université Mohammed V-Agdal, Rabat, Morocco, Ph.D. thesis, 2003, https://www.researchgate.net/ publication/237081221_Monographie_des_Poissons_des_ eaux_continentales_du_Maroc_systematique_ distribution_et_ecologie.

[13] AOAC, AOAC Official Method 999.10, Lead, Cadmium, Zinc, Cooper, and Iron in Foods, Atomic Absorption Spectrophotomoetry after Micowave Digestion, AOAC, Rockville, MD, USA, 2002.

[14] ISO/IEC 17025, "General requirements for the competence of testing and calibration laboratories," 2017, https://www.iso. org/obp/ui/\#iso:std:iso-iec:17025:ed-3:v1:en.

[15] USEPA (United States Environmental Protection Agency), Guidance for Assessing Chemical Contaminant Data for Use in Fish Advisories, Office of Water, vol. 1, https://www.epa.gov/ sites/production/files/2018-11/documents/guidance-assesschemical-contaminant-vol1-third-edition.pdf, 2000.

[16] C. Vieira, S. Morais, S. Ramos, C. Delerue-Matos, and M. B. P. P. Oliveira, "Mercury, cadmium, lead and arsenic levels in three pelagic fish species from the Atlantic Ocean: Intra- and inter-specific variability and human health risks for consumption," Food and Chemical Toxicology, vol. 49, no. 4, pp. 923-932, 2011.

[17] M. Diop, S. Net, M. Howsam et al., "Concentrations and potential human health risks of trace metals $(\mathrm{Cd}, \mathrm{Pb}, \mathrm{Hg})$ and selected organic pollutants (PAHs, PCBs) in fish and seafood from the Senegalese coast," International Journal of Environmental Research, vol. 11, no. 3, pp. 349-358, 2017.

[18] W. Xia, L. Chen, X. Deng et al., "Spatial and interspecies differences in concentrations of eight trace elements in wild freshwater fishes at different trophic levels from middle and eastern China," Science of the Total Environment, vol. 672, pp. 883-892, 2019.

[19] HCP (Haut Commissariat au Plan), "Enquête Nationale sur la Consommation et les Dépenses des Ménages 2013/2014," HCP, Rapport de Synthèse, Royaum du Maroc, 2014, https:// www.hcp.ma/file/204566/

[20] S. Mounach, L. Belakhel, N. Bennani et al., "Enquête nationale sur les facteurs de risque communs des maladies non transmissibles," Ministère de la Santé Marocaine/Organisation Mondiale de la Santé, Rapport, 2018, https://www.sante.gov.ma/ Documents/2019/05/Rapport\%20de\%201\%20enqu\%C3\%AAte \%20Stepwise.pdf.

[21] M. M. Storelli, "Potential human health risks from metals ( $\mathrm{Hg}$, $\mathrm{Cd}$, and $\mathrm{Pb}$ ) and polychlorinated biphenyls (PCBs) via seafood consumption: estimation of target hazard quotients
(THQs) and toxic equivalents (TEQs)," Food and Chemical Toxicology, vol. 46, no. 8, pp. 2782-2788, 2008.

[22] M. Metian, M. Warnau, T. Chouvelon, F. Pedraza, A. M. Rodriguez y Baena, and P. Bustamante, "Trace element bioaccumulation in reef fish from New Caledonia: Influence of trophic groups and risk assessment for consumers," Marine Environmental Research, vol. 87, pp. 26-36, 2013.

[23] FAO/WHO, Summary of Evaluations Performed by the Joint FAO/WHO Expert Committee on Food Additives (JECFA 1956-2003), (First through Sixty-First Meetings), ILSI Press International Life Sciences Institute, Washington, DC, USA, 2004.

[24] S. Rajeshkumar and X. Li, "Bioaccumulation of heavy metals in fish species from the meiliang bay, Taihu lake, China," Toxicology Reports, vol. 5, pp. 288-295, 2018.

[25] The Commission of the European Communities, "Commission regulation (EC) $\mathrm{N}^{\circ} 1881 / 2006$ of 19 December 2006, setting maximum levels for certain contaminants in foodstuffs," Official Journal of the European Union, https://eur-lex.europa.eu/legalcontent/EN/TXT/PDF/?uri=CELEX:32006R1881\&from=EN, 2006.

[26] M. Mahjoub, M. EL Maadoudi, and Y. Smiri, "Metallic contamination of the muscles of three fish species from the Moulouya River (lower Moulouya, eastern Morocco)," International Journal of Ecology, vol. 2020, Article ID 8824535, 8 pages, 2020.

[27] R. Merciai, H. Guasch, A. Kumar, S. Sabater, and E. GarcíaBerthou, "Trace metal concentration and fish size: variation among fish species in a Mediterranean river," Ecotoxicology and Environmental Safety, vol. 107, pp. 154-161, 2014.

[28] A. Shakeri, R. Shakeri, and B. Mehrabi, "Potentially toxic elements and persistent organic pollutants in water and fish at Shahid Rajaei Dam, north of Iran," International Journal of Environmental Science and Technology, vol. 12, no. 7, pp. 2201-2212, 2015.

[29] S. A. S. Petkovšek, Z. M. Grudnik, and B. Pokorny, "Heavy metals and arsenic concentrations in ten fish species from the Šalek lakes (Slovenia): assessment of potential human health risk due to fish consumption," Environmental Monitoring and Assessment, vol. 184, pp. 2647-2662, 2012.

[30] A. Boscher, S. Gobert, C. Guignard et al., "Chemical contaminants in fish species from rivers in the North of Luxembourg: potential impact on the Eurasian otter (Lutra lutra)," Chemosphere, vol. 78, no. 7, pp. 785-792, 2010.

[31] C. Plessl, B. M. Gilbert, M. F. Sigmund et al., "Mercury, silver, selenium and other trace elements in three cyprinid fish species from the Vaal Dam, South Africa, including implications for fish consumers," Science of the Total Environment, vol. 659, pp. 1158-1167, 2019.

[32] M. N. Rashed, "Monitoring of environmental heavy metals in fish from Nasser Lake," Environment International, vol. 27, no. 1, pp. 27-33, 2001.

[33] H. Özparlak, G. Arslan, and E. Arslan, "Determination of some metal levels in muscle tissue of nine fish species from Beyşehir Lake, Turkey," Turkish Journal of Fisheries and Aquatic Sciences, vol. 12, pp. 761-770, 2012.

[34] M. Bahnasawy, A. A. Khidr, and N. Dheina, "Seasonal variations of heavy metals concentrations in mullet, Mugil cephalus and Liza ramada (Mugilidae) from Lake Manzala, Egypt," Egyptian Journal of Aquatic Biology and Fisheries, vol. 13, no. 2, pp. 81-100, 2009.

[35] J. W. Rajotte and P. Couture, "Effects of environmental metal contamination on the condition, swimming performance, and tissue metabolic capacities of wild yellow perch (Perca 
flavescens)," Canadian Journal of Fisheries and Aquatic Sciences, vol. 59, no. 8, pp. 1296-1304, 2002.

[36] B. M. Gilbert and A. Avenant-Oldewage, "Arsenic, chromium, copper, iron, manganese, lead, selenium and zinc in the tissues of the largemouth yellowfish, Labeobarbus kimberleyensis (Gilchrist and Thompson, 1913), from the Vaal Dam, South Africa, and associated consumption risks," Water SA, vol. 40, no. 4, pp. 739-748, 2014.

[37] B. El Bouhali, L. Bennasser, I. Nasri et al., "Contamination métallique de Gambusia holbrooki au niveau du lac Fouarat et de l'estuaire Sebou dans la région du Gharb (Maroc)," Afrique Science, vol. 4, no. 3, pp. 410-425, 2008.

[38] F. Wariaghli, A. Tigilliman, A. El abidi et al., "Evaluation of the degree of heavy metal contamination in the Sebou estuary and in Moulay Bousselham lagoon reserve (Morocco)," International Journal of Aquatic Science, vol. 4, no. 2, pp. 69-82, 2013.

[39] E. Alhas, S. A. Oymak, and H. K. Akin, "Heavy metal concentrations in two barb, Barbus xanthopterus and Barbus rajanorum mystaceus from Atatürk Dam Lake, Turkey," Environmental Monitoring and Assessment, vol. 148, pp. 1118, 2009.

[40] L. Noël, R. Chekri, S. Millour et al., "Distribution and relationships of $\mathrm{As}, \mathrm{Cd}, \mathrm{Pb}$ and $\mathrm{Hg}$ in freshwater fish from five French fishing areas," Chemosphere, vol. 90, no. 6, pp. 1900-1910, 2013.

[41] Z. Jiang, N. Xu, B. Liu et al., "Ecotoxicology and environmental safety metal concentrations and risk assessment in water, sediment and economic fish species with various habitat preferences and trophic guilds from Lake Caizi, Southeast China," Ecotoxicology and Environmental Safety, vol. 157, pp. 1-8, 2018.

[42] Y. Yi, Z. Wang, K. Zhang et al., "Sediment pollution and its effect on fish through food chain in the Yangtze River," International Journal of Sediment Research, vol. 23, no. 4, pp. 338-347, 2008.

[43] M. I. Castro-González and Méndez-Armenta, "Heavy metals: implications associated to fish consumption," Environmental Toxicology and Pharmacology, vol. 26, no. 3, pp. 263-271, 2008.

[44] N. Nasyitah Sobihah, A. Ahmad Zaharin, M. Khairul Nizam et al., "Bioaccumulation of heavy metals in maricultured fish, Lates calcarifer (Barramudi), Lutjanus campechanus (red snapper) and Lutjanus griseus (grey snapper)," Chemosphere, vol. 197, pp. 318-324, 2018.

[45] H. Karadede and E. Unlu, "Concentrations of some heavy metals in water, sediment and fish species from the Ataturk Dam Lake (Euphrates), Turkey," Chemosphere, vol. 197, no. 41, pp. 1371-1376, 2000.

[46] S. Mol, Ö. Özden, and S. A. Oymak, "Trace metal contents in fish species from Ataturk Dam Lake (Euphrates, Turkey)," Turkish Journal of Fisheries and Aquatic Sciences, vol. 10, pp. 209-213, 2010.

[47] P. S. Dharampal and R. H. Findlay, "Mercury levels in largemouth bass (Micropterus salmoides) from regulated and unregulated rivers," Chemosphere, vol. 170, pp. 134-140, 2017.

[48] R. Scerbo, T. Ristori, B. Stefanini et al., "Mercury assessment and evaluation of its impact on fish in the Cecina river basin (Tuscany, Italy)," Environmental Pollution, vol. 135, no. 1, pp. 179-186, 2005.

[49] A. Maceda-Veiga, M. Monroy, and A. de Sostoa, "Metal bioaccumulation in the Mediterranean barbel (Barbus meridionalis) in a Mediterranean River receiving effluents from urban and industrial wastewater treatment plants,"
Ecotoxicology and Environmental Safety, vol. 76, no. 1, pp. 93-101, 2012.

[50] F. P. Arantes, L. A. Savassi, H. B. Santos et al., "Bioaccumulation of mercury, cadmium, zinc, chromium, and lead in muscle, liver, and spleen tissues of a large commercially valuable catfish species from Brazil," Anais da Academia Brasileira de Ciências, vol. 88, no. 1, pp. 137-147, 2016.

[51] N. Pourang and J. H. Dennis, "Distribution of trace elements in tissues of two shrimp species from the Persian Gulf and roles of metallothionein in their redistribution," Environment International, vol. 31, no. 3, pp. 325-341, 2005.

[52] E. Garcia-Berthou and R. Moreno-amich, "Rudd (Scardinius erythrophthalmus) introduced to the Iberian peninsula: feeding ecology in Lake Banyoles," Hydrobiologia, vol. 436, pp. 159-164, 2000.

[53] R. Merciai, C. Rodriguez-Prieto, J. Torres et al., "Bioaccumulation of mercury and other trace elements in bottomdwelling omnivorous fishes: the case of Diplodus sargus (L.) (Osteichthyes: sparidae)," Marine Pollution Bulletin, vol. 136, pp. 10-21, 2018.

[54] C. Shinn, F. Dauba, G. Grenouillet et al., "Temporal variation of heavy metal contamination in fish of the river lot in southern France," Ecotoxicology Environmental Safety, vol. 72, no. 7, pp. 1957-1965, 2009.

[55] K. Sunjog, S. Kolarević, M. Kračun-Kolarević et al., "Seasonal variation in metal concentration in various tissues of the European chub (Squalius cephalus L.)," Environmental Science and Pollution Research, vol. 26, no. 9, pp. 9232-9243, 2019.

[56] A. Kassegne, T. Berhanu, J. Okonkwo, and S. Leta, "Assessment of trace metals in water samples and tissues of African catfish (Clarias gariepinus) from the akaki river catchment and the aba samuel reservoir, central Ethiopia," African Journal of Aquatic Science, vol. 44, no. 4, pp. 389-399, 2019.

[57] E. E. Obasohan, "The use of heavy metals load as an indicator of the suitability of the water and fish of Ibiekuma stream for domestic and consumption purposes," African Journal of Biotechnology, vol. 7, no. 23, pp. 4345-4348, 2008. 